\title{
BLM wt Allele
}

National Cancer Institute

\section{Source}

National Cancer Institute. BLM wt Allele. NCI Thesaurus. Code C49406.

Human BLM wild-type allele is located in the vicinity of $15 q 26.1$ and is approximately 98 $\mathrm{kb}$ in length. This allele, which encodes Bloom syndrome protein, plays a role in the unwinding of single- and double-stranded DNA in a 3'-5' direction during DNA replication and repair. Defects in the BLM gene cause Bloom syndrome. 